\section{Dengue: twenty-five years since reemergence in Brazil}

\author{
Dengue: vinte e cinco anos da reemergência no \\ Brasil
}

\section{Instituto de Saúde Coletiva, Universidade Federal da Bahia, Salvador, Brasil. \\ Correspondence M. G. Teixeira \\ Instituto de Saúde Coletiva, Universidade Federal da Bahia. Rua Basílio da Gama s/n, Campus Universitário Canela, Salvador, BA 40110-040, Brasil. magloria@ufba.br}

\section{Abstract}

This article revisits the epidemiology of dengue in Brazil, 25 years after its reemergence in the country, discussing the main determinants and implications for its control. The authors emphasize the clinical and epidemiological peculiarities of this viral disease in Brazil, which leads the world in both the number of cases reported and risk of occurrence of the disease. The article presents the changes occurring in the dengue epidemiological pattern in recent years, like the sudden age shift in the incidence of dengue hemorrhagic fever, and discusses possible associated factors. The article focuses specifically on the epidemic in Rio de Janeiro in 2008, this episode's impact on the international community, and the fear that the disease could spread to Europe. The authors conclude that the current situation emphasizes the need for the international scientific community to renew its efforts to generate knowledge allowing improvement and progress in the development of new tools and strategies for dengue prevention.

Aedes aegypti; Dengue; Communicable Diseases

\author{
Maria Glória Teixeira 1 \\ Maria da Conceição N. Costa 1 \\ Florisneide Barreto 1 \\ Maurício Lima Barreto 1
}

\section{Introduction}

In the $21^{\text {st }}$ century Brazil became the country of the world with the most reported cases of dengue fever, occupying first place in the international ranking for total cases of the disease, with more than three million cases reported from 2000 to 2005 . This represented $78 \%$ of all cases reported in the Americas and $61 \%$ of all cases reported to the World Health Organization (WHO) 1, making Brazil the country with the second to eighth highest risk for this disease, among countries with more than a million inhabitants 1 . The incidence in Brazil varied from 446.3 to 63.2 per 100 thousand inhabitants, in 2002 and 2004, respectively 2 .

Until the mid-1990s, Southeast Asia was the region of the world that was most heavily affected by dengue. Since then, the disease has increased in countries in Central and South America, which have contributed far more than half of the world's reported cases. During the 1990s, in one year alone (1998), Brazil reported more than 700 thousand cases 1 .

Important differences have been observed in dengue epidemiology in the Americas versus Southeast Asia, including a lower proportion of cases of dengue hemorrhagic fever in the Americas within a high incidence of dengue fever cases 1,3 . The four dengue serotypes circulate in the Americas, and in Brazil, DEN-1, DEN-2, and DEN-3 have circulated simultaneously since 
1991. This situation, according to Halstead's hypothesis of sequential infections, represents an important risk factor for the occurrence of dengue hemorrhagic fever due to the immune amplification phenomenon, or the formation of immune complexes resulting from the presence of antibodies to one of the dengue serotypes in individuals infected by a new serotype. This process is the basis for triggering the pathophysiological processes accounting for the clinical manifestations of dengue hemorrhagic fever 4,5.

Another difference between the two regions is the age bracket at highest risk. In Southeast Asia dengue is predominantly a childhood disease, whereas in Brazil as of 2006, the incidence of dengue fever, dengue hemorrhagic fever, and even clinically unapparent dengue virus infection was much higher in adults 6,7,8. Still, in the epidemic that exploded in the summer of 2008 in Rio de Janeiro, Brazil's second largest city, there was a sudden rise in the incidence among individuals younger than 15 years, both for dengue fever and dengue hemorrhagic fever ${ }^{9}$. However, this age shift had already been occurring (although less visibly) in hospital admissions for dengue hemorrhagic fever since 2007 in Brazil as a whole (Sistema de Informações Hospitalares. http://w3.datasus.gov.br/siasih/siasih.php, accessed on 13/Mar/2008).

The peculiar clinical and epidemiological characteristics of dengue in Brazil have sparked the interest of Brazilian and international public health researchers and agencies, given the importance of identifying the factors that determine the different forms of individual and collective expression of these infections with a view towards improving the control and treatment of this viral disease, the world's second most important vector-borne disease in terms of number of cases 10 .

Meanwhile, the possibility of increased occurrence of dengue hemorrhagic fever has become the object of concern for all of society and especially for health authorities, due to the difficulties in controlling the epidemics produced by this virus and the need to expand the installed capacity of health services to treat dengue patients. A striking and very current example is the above-mentioned epidemic in the city of Rio de Janeiro, which also affected other cities in the State of Rio de Janeiro, where in the first four months of 2008 alone there were more than 155 thousand cases of dengue fever (incidence of 2,543.7/100 thousand inhabitants), more than 9 thousand hospitalizations, more than a thousand cases of dengue hemorrhagic fever, and 110 deaths, of which nearly half were children 9,11 .
Without overlooking the prevailing difficulties in local health systems in Brazil, it is not surprising that such situations lead to a collapse in medical care, since the magnitude of such an epidemic would exceed any health system's installed capacity. Health authorities experienced obvious difficulties in controlling the epidemic, and the situation caused panic and insecurity in all of Brazilian society. The episode reiterated this disease's relevance as a public health problem, triggering great international outcry 11 and exacerbating institutional policy problems to respond adequately to the population's needs during this emergency situation.

Given the complex and dynamic process involving the occurrence of dengue, as evidenced by the rapid expansion, severity, magnitude, and changes in its collective and individual expression, the aim of this article is to revisit the epidemiology of this disease 25 years after its reemergence in Brazil, as well as to discuss some of the principal determinants and implications for its control.

\section{Factors that condition the occurrence of dengue virus infections}

According to Gubler 12 the emergence of dengue as a global health problem is still not fully understood. Evidently, the biological characteristics of the dengue virus (four serotypes, virulence of strains, sequence of infections, replication rate, etc.), host (race, age, immune system, etc.), and vector (reproduction rate, adaptation to the environment, etc.) are important factors in determining the incidence and severity of infections 13 . Still, the population growth associated with unplanned and uncontrolled urbanization, principally in countries with a tropical climate creating the ideal conditions for the proliferation of Aedes aegypti, increased international travel flow, facilitating spread of the dengue virus, and reduction in resources for programs to control and prevent vector-borne infectious diseases contribute jointly to shaping this situation. These factors largely explain the international spread of dengue, but it is important to understand the dynamics of the circulation of this virus in each geographic and social space.

The space human beings inhabit plays a central role in determining the circulation of dengue virus serotypes and the production of dengue (Figure 1) 13,14. In the process of occupying space in modern cities, particularly in developing countries like Brazil, humans have created the conditions for the occurrence of many diseases and injuries 15, and in the specific case of dengue 
these conditions are extremely favorable for its biological cycle (virus-vector-man). This chain is established in different ways in each social space, so that circulation of the viral serotypes occur in populations with different degrees of herd immunity, abundance of the mosquito vector, flow of persons, population density, turnover rate of susceptible individuals, and other factors that greatly influence the incidence and severity of the disease $12,16,17,18$.

The force of dengue virus transmission is extremely high, comparable to that of transmissible diseases that spread by contagion 19 . Thus, it is no coincidence that even only 25 years since reemergence of dengue, Brazil has become the country of the world that produces the most cases. Based on different serological surveys in the country 20,21,22, important population contingents already have antibodies to one or more of its serotypes. Brazil has broad stretches of territory with highly favorable climate for the proliferation of Ae. aegypti 23 and dozens of metropolises with high human population density living in substandard clusters with precarious social, economic, and infrastructure conditions, particularly in relation to water supply and garbage collection. The current way of life for Brazilian urban populations has generated (on an exponential scale) the habitats for Ae. aegypti 13,24,25 to lay its eggs and thus to proliferate both in areas with deficient sanitation and in other areas with adequate sanitation, thus facilitating intense viral transmission 20,21,22.

This apparent paradox can be observed in Brazil through the spatial distribution of seroprevalence of dengue virus infections: in some cities, the risk is high both in neighborhoods with more favorable socioeconomic conditions and in those with precarious living conditions $20,21,22$, while in other cities the poorest population has been hit more heavily 14,26,27. In one Brazilian city, the risk of dengue virus infection, even among residents of the same neighborhood, was higher among those living in nonvertical buildings 26 .

\section{Revisiting dengue epidemiology in Brazil}

The reintroduction of Ae. aegypti in the latter half of the 1970s 28 , in a country like Brazil with a tropical climate, where the environmental conditions are receptive to this vector, during a period in which entomological surveillance and the structure to fight the vector were nearly deactivated, allowed not only its introduction in other strategic points but also its unchecked territorial expansion 13 .

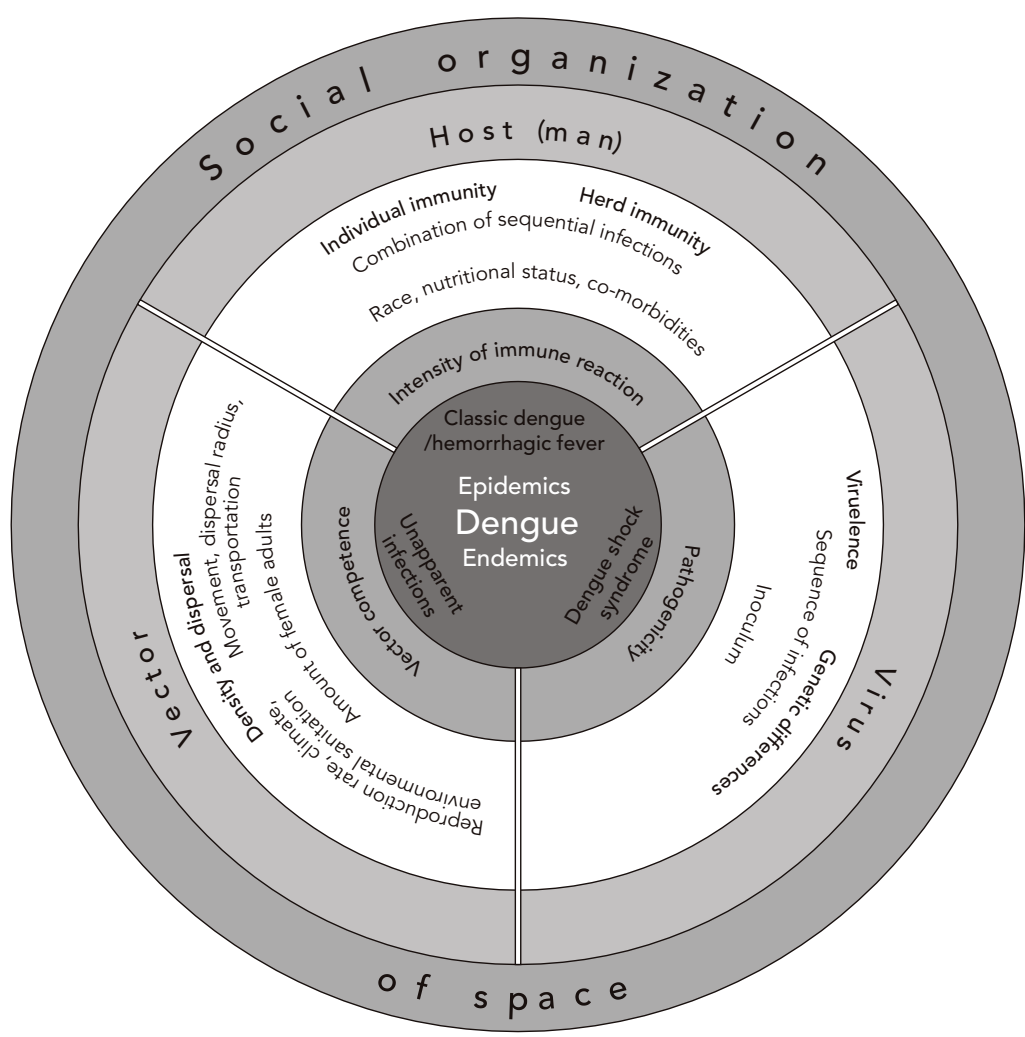

Source: Teixeira et al. 13 .

Although the first dengue epidemic with viral isolation occurred in 1981, in Boa Vista, Roraima State 29, it was not until 1986, when the DEN-1 serotype was introduced into Rio de Janeiro, that the disease became a major public health problem. The following year, some State capitals of the Northeast were already affected, and the incidence reached 64.6 per 100 thousand inhabitants (Figure 2), and the total number of accumulated cases reported in two years reached 134,721. The transmission force of the dengue virus was so intense that according to estimates based on a serological survey in 1986 and 1987 in Rio de Janeiro, more than a million persons had been infected with DEN-1 30 . Since in the subsequent years the environmental conditions remained receptive to circulation of the dengue virus, in 1990 DEN-2 was introduced, also in Rio de Janeiro, with a recrudescence of dengue fever and the first reported cases of dengue hemorrhagic fever 7 . 
Beginning in 1994, circulation of the virus expanded to more than 600 municipalities distributed in 18 States of Brazil, with a progressive increase in the incidence of the disease in the country. In 1998, the incidence reached 345.7 cases per 100 thousand inhabitants (Figure 2), and that same year dengue underwent a major expansion in the world 1 . In 1999, some $50 \%$ of Brazil's 5,507 municipalities had already reported dengue fever cases and Ae. aegypti had already been detected in $64 \%$ of them. The proportion of dengue hemorrhagic fever cases in the 1990s was relatively low $(0.06 \%)$, considering the intense simultaneous circulation of serotypes DEN-1 and DEN-2 7 .

Dengue incidence in the first two years of the $21^{\text {st }}$ century in Brazil remained high (141.0 and 239.4 cases per 100 thousand inhabitants in 2000 and 2001, respectively). With the introduction of DEN-3 in 2002, there was a dramatic increase in both dengue fever (446.2 cases per 100 thousand inhabitants, Figure 2) and dengue hemorrhagic fever, for which the reported cases $(2,702)$ represented $0.34 \%$ of all reported dengue cases $(794,219)$. Serotype DEN-3 spread rapidly to the majority of Brazilian territory, practically displacing serotypes DEN-1 and DEN-2 from various cities and States of the country in the subsequent years 7 .

Between 1981 and 2007, 4,463,102 cases of dengue were reported in Brazil (Table 1), of which more than three million occurred from 2000 to June 2007 , when $72 \%$ of the country's municipalities $(3,977 / 5,507)$ were already infested with $A e$. aegypti 2 . From 2000 to 2007 there was a major increase in the number of cases of dengue hemorrhagic fever $(6,455)$, accounting for $0.21 \%$ of all reported dengue cases. This proportion, although 3.5 times higher than in the 1990s, is still considered relatively low as compared to Southeast Asia ${ }^{3}$. This difference has sometimes been ascribed to non-recognition of many dengue hemorrhagic fever cases by health professionals in Brazil 3 , but if the majority of cases were really not being diagnosed by health services or were confused with some other disease, the situation would tend to call the attention of health authorities due to the severity of this form of the disease.

Figure 2

Dengue fever incidence rates (per 100 thousand inhabitants) according to geographic regions and year of occurrence. Brazil, $1986-2007$.

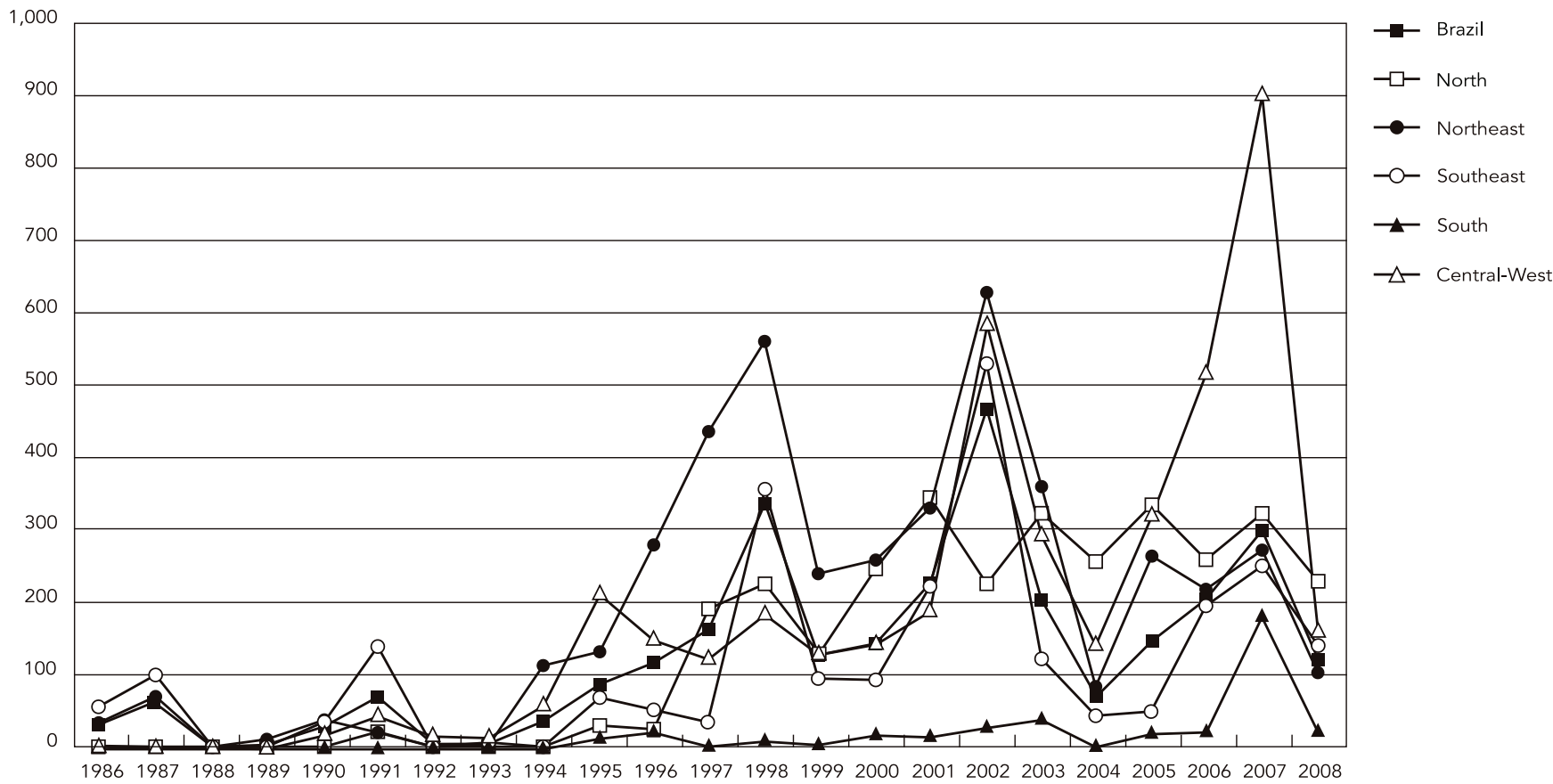

Source: National Dengue Control Program 2. 
Number of municipalities (counties) with Aedes aegypti and dengue transmission, accumulated cases of dengue fever and dengue hemorrhagic fever, Brazil and regions, 2007 *

\begin{tabular}{lcccc}
\hline Regions & $\begin{array}{c}\text { Municipalities with } \\
\text { Aedes aegypti }\end{array}$ & $\begin{array}{c}\text { Municipalities with } \\
\text { dengue transmission }\end{array}$ & $\begin{array}{c}\text { Accumulated number of cases } \\
\text { Dengue fever ** }\end{array}$ & $\begin{array}{c}\text { Dengue hemorrhagic } \\
\text { fever } * * *\end{array}$ \\
\hline North & 336 & 155 & 358,473 & 347 \\
Northeast & 1,682 & 1,173 & $1,891,071$ & 3,023 \\
Southeast & 1,187 & 856 & $1,663,514$ & 3,811 \\
South & 323 & 252 & 93,924 & 12 \\
Central-West & 449 & 320 & 456,120 & 674 \\
Brazil & 3,977 & 2,756 & $4,463,102$ & 7,867 \\
\hline
\end{tabular}

Source: National Dengue Control Program 2.

* Data until week 51;

** Accumulated total from 1981 to 2007;

*** Accumulated total from 1990 to 2007

The large African descendent contingent of the Brazilian population, amplified by the high degree of racial miscegenation in various regions of the country, has been cited as one explanation for the lower observed risk of dengue hemorrhagic fever in Brazil, even in the presence of a high dengue fever rate and the hyperendemicity of three dengue virus serotypes, since some case series studies have shown a higher frequency of severe forms of dengue in European descendents 3,31. Recently, in Salvador, Bahia, a city of Brazil in which $80 \%$ of the population selfidentifies as black or mixed-race, it was shown for the first time that African descendent ethnicity confirmed by genetic markers of African ancestry had a protective effect against dengue hemorrhagic fever 32 , a finding that doubtless strengthens the hypothesis mentioned above.

Currently, case-fatality rates below $1 \%$ for dengue hemorrhagic fever are considered acceptable, but in Brazil this indicator is still extremely high (Figure 3), varying from $1.45 \%$ (1995) to $11.25 \%$ (2007). Importantly, in Brazil the case-fatality rate is estimated using only dengue hemorrhagic fever cases as the denominator, while in many other countries the total number of dengue cases is used, making comparison with these other countries impossible. The Brazilian health authorities have adopted such measures as training of health professionals, organization of health services during epidemic periods, and development of public awareness campaigns on warning signs for the disease, aimed at early diagnosis and treatment of dengue hemorrhagic fever in order to reduce the number of fatal cases.
Until 1996, dengue virus circulation in Brazil was more intense in cities with more than 500 thousand inhabitants, especially coastal State capitals like Rio de Janeiro, Salvador, Fortaleza, Recife, Natal, and others 23. A study of the first dengue epidemic in Salvador, capital of the State of Bahia, showed centrifugal propagation of cases, characterizing a pattern of spread by expansion with a well-defined epicenter, similar to the process of spread by contagion and different from what usually occurs with a vector-borne disease like dengue 19,33. A similar phenomenon may occur in the other Brazilian metropolises, inducing the occurrence of epidemics that propagate rapidly to practically the entire city, reaching significant portions of the population.

In 1997, dengue began to occur at higher rates in small cities, principally those situated in the interior of the North, Northeast, and Central-West, which correspond to the territorial stretches of Climatic Units that are more favorable to proliferation of Ae. aegypti (Tropical Eastern Northeast, Tropical Equatorial Zone, and Tropical Central Zone) ${ }^{23}$. This trend became even more evident in 2007 , when approximately $40 \%$ of dengue cases in Brazil came from municipalities with fewer than 100 thousand inhabitants 2 .

Although reporting of dengue fever cases helps detect trends in the disease, the existence of a considerable proportion of subclinical or unapparent infections means that these data alone do not provide a clear picture of viral circulation dynamics. Thus, serological surveys to determine the seroprevalence or seroincidence of dengue antibodies In order to estimate the real magni- 
Figure 3

Cases and deaths, dengue hemorrhagic fever, by geographic region. Brazil, 1990-2007.

3a) Cases of dengue hemorrhagic fever

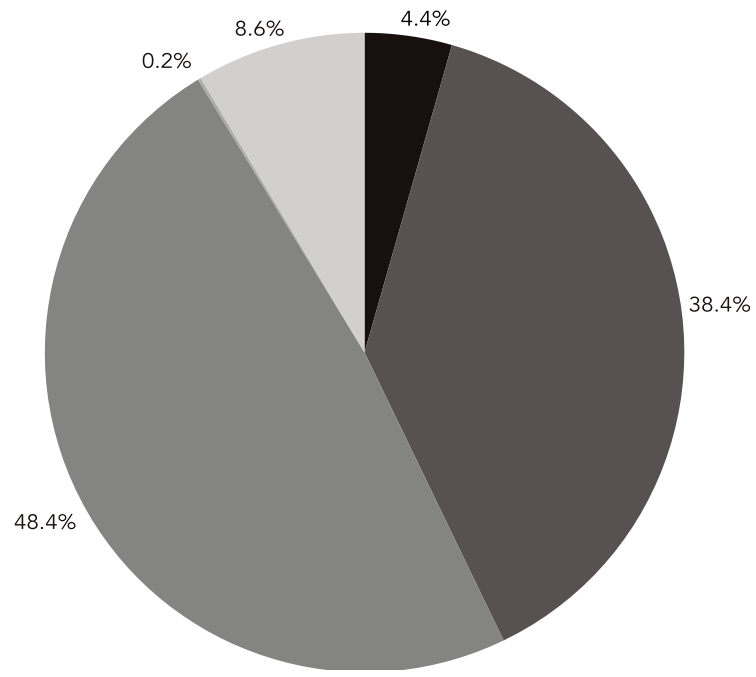

North

Northeast

Southeast

South

Central-West

3b) Deaths

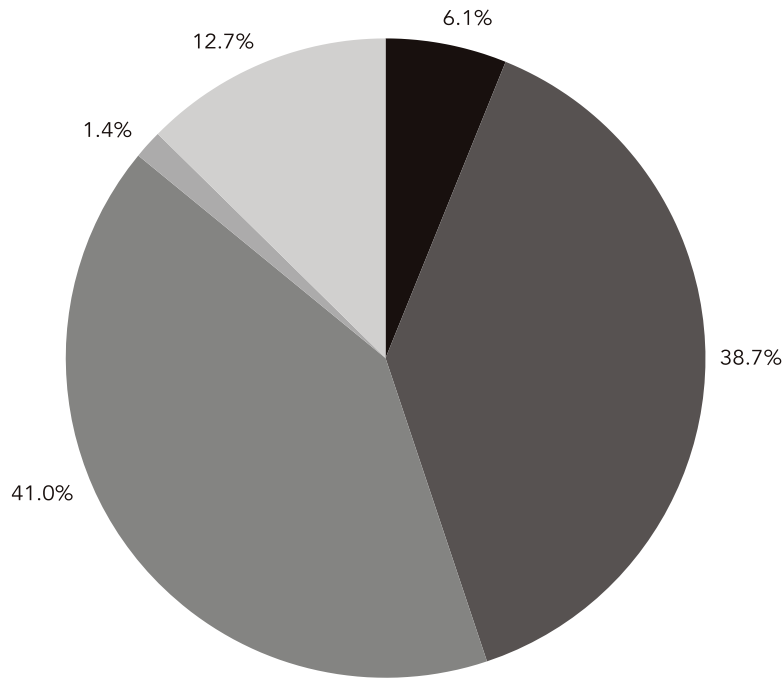

Source: National Dengue Control Program 2.

tude of these infections have been performed in various Brazilian cities. Such studies have shown that millions of Brazilians already have antibodies to at least one of the dengue virus serotypes, and are thus at increased risk of developing dengue hemorrhagic fever. The mean seroprevalence rates have varied among the areas studied, with the highest rates in Mossoró (97.8\%) 23, Salvador
(67\%) 20, Niterói (66\%) 34, Macapá (48.4\%) 23, Rio de Janeiro (44.5\%) 30 , Fortaleza (44\%) 21 , and São Luís $(41.4 \%) 22$. Lower rates were found in Goiânia $(29.5 \%) 35$, Belo Horizonte (23.3\%) 26 , and Ribeirão Preto (5.4\%) 36 . The variations result from the diversity in the distribution of determinant factors in each geographic space in this country of continental dimensions, particularly in the climatic diversity and population density, in addition to the time elapsed between the initial viral circulation and the serological surveys, the circulating serotypes, and other factors.

Both the dengue fever and dengue hemorrhagic fever epidemics in Brazil had been characterized by a higher incidence in the adult population 6,7,20,21,22,37, a different pattern from that in most of Southeast Asia, where both forms of the disease are more frequent in children 38,39 . However, in the first semester of 2007 there was a sudden change in the pattern observed in Brazil, with a significant increase in the proportion of dengue hemorrhagic fever cases in the under-15-year age bracket (Figure 4), especially in the Northeast. This phenomenon appears not to be transient, given the epidemic that hit Rio de Janeiro in the early months of 2008 , when some $50 \%$ of the dengue fever cases and $86 \%$ of deaths occurred in individuals under 15 years 9 . Given that during the 1990s in Brazil, both DEN-2 and DEN-1 circulated predominantly among individuals older than 15 years, significant portions of the Brazilian adult population currently have antibodies to these serotypes. Beginning in 2000-2001, with the introduction of DEN-3, this serotype spread rapidly to hundreds of Brazilian cities, with a near-total displacement of the previously cited serotypes. Since DEN-2 began predominating again in some cities in 2007, the currently observed age shift may be due to the replenishment of the reserve of DEN-2 susceptible individuals, which began to consist of children.

More recently, many cases of dengue hemorrhagic fever have been diagnosed in patients without primary dengue infection, that is, individuals without antibodies from previous infections 37,40. Since such cases do not fit with the premises of the Halstead hypothesis of sequential infections ${ }^{4}$, research is needed to elucidate which other factors are involved, such as viral strain virulence, as reported since the 1970s 41 , host genetics 32 , presence of co-morbidtiy 37,39 , and others that can contribute to dengue severity.

While the occurrence of dengue in Brazil displays some peculiarities, important aspects of its epidemiological profile have evolved in a similar way to that in Southeast Asia since the 1950 s, e.g., the magnitude of dengue fever epidemics lasting two years, followed by a reduction 


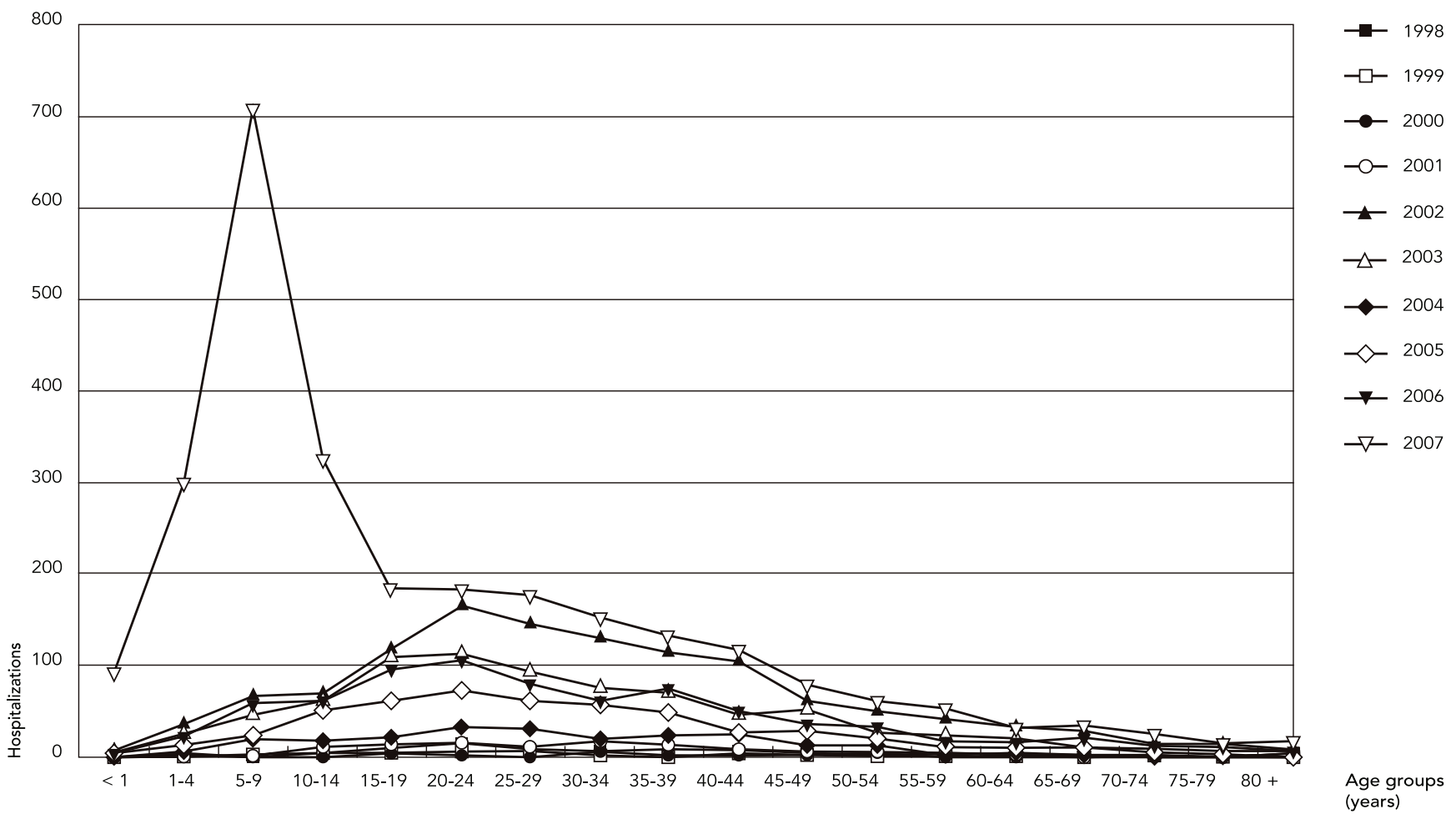

in the incidence during the following two years, and greater intensity of transmission during the hot, rainy months of the year 6,7,13,19,42,43. However, as already discussed, in Brazil the incidence of dengue hemorrhagic fever is lower, and until 2006 both dengue fever and dengue hemorrhagic fever occurred predominantly in adults 6,7,37. Atypical manifestations of dengue (neurological, hepatic, and cardiac, among others) have been described both in Brazil 37,44,45,46,47,48,49,50 and in other countries of the Americas and Southeast Asia 51, but the lack of epidemiological studies on their incidence does not allow comparisons.

\section{Limits and challenges for dengue control}

The focus for controlling dengue virus infections is based on fighting Ae. aegypti, due to the lack (to date) of safe and effective vaccines for use in populations. Over the course of these 25 years in which the Brazilian population has lived with dengue epidemics, the country has invested considerable resources to fight the vector. The current control program adopts an integrated model aimed at synergy of activities and obtaining more consistent results, as recommended by the WHO 52 . Ten components have been developed simultaneously, involving not only activities to eliminate Ae. aegypti but also environmental sanitation, epidemiological and health surveillance, laboratory support, and health information and education measures, among others 53.

The current epidemiological situation with dengue shows that these program measures have not achieved success. Epidemiological impact assessments of these interventions have shown that their effectiveness is extremely limited 20,23. Regardless of each local health system's operational and administrative difficulties, even when these measures are well managed, their effectiveness is always low, given the intense viral circulation detected in the successive epidemics and the results of serological surveys conducted in various Brazilian cities 6,20,21,22,23,54. 
Importantly, all the countries where the dengue virus circulates are facing the fact that it is impossible to eliminate Ae. aegypti. Even where programs to combat the vector have been well structured and the infestation rates have been maintained relatively low, as in Singapore and Cuba 38,55, the dengue virus has circulated with great intensity. This phenomenon is a function of favorable environmental conditions for proliferation and survival of this mosquito between latitude $35^{\circ}$ North and $35^{\circ}$ South and the transmission force of the dengue virus in the presence of a large number of susceptible individuals 38,54,56.

Some Brazilian cities have succeeded in improving the vector control program and reducing the domiciliary and peri-domiciliary infestation rates, the principal target of measures to eliminate the mosquito, as in Belo Horizonte, where from 2003 to 2007 the mean building infestation rate varied from 0.3 to $0.6 \%$, except in 2006 when it increased to $1.5 \% 2$. Even so, in 2007 there was a sudden increase in dengue incidence in the city, and an entomological survey showed that there were also foci located outside of households (for example, in underground telephone installations), which possibly contributing to the increase in the winged Ae. aegypti population. This vector's adaptive capacity has been observed in both the Americas and Southeast Asia, and as discussed above, consists of factors that hinder attempts to combat it. Changes have been observed in dengue epidemiology itself due to adaptation by Ae. aegypti to new environmental situations. In Singapore, bus stops and schools have apparently become the principal sites for acquiring dengue infections, rather than the intra-domicile as previously 38 .

As emphasized, prevailing contemporary socio-cultural factors in most human societies have greatly facilitated the vector's survival and proliferation in human habitats, while hindering attempts to combat it. Such factors also contribute to the reduced effectiveness of vector control, the exponential growth in the number of potential breeding sites that guarantee the mosquito ability to lay eggs, and the hatching of larvae and the impossibility of establishing a comprehensive struggle against the mosquito, due to the repetitive and exhaustive household visits. The population considers such visits intrusive, and such measures also fail to encourage individual responsibility in terms of environmental education, to the extent that government implements certain measures in the private domain that should be taken by the residents themselves.

Dengue-related educational activities in Brazil have been insufficiently evaluated, since the population absorbs the messages, but fails to change its practices and habits, leaving a gap between knowledge and behavior. The strategies used to transmit information may not be adequate, since they have failed to result in changes in practices to foster the maintenance of indoor and outdoor household environments free of mosquito breeding sites $57,58,59$.

Such observations indicate the need to improve or replace the vector control technologies and strategies, due to the limited scientific progress in this field. Research efforts have been made in this direction, mainly from the perspective of genetic modifications in the vector, development of traps capable of suppressing winged forms 52,60,61,62,63, and the incorporation of new pedagogical practices favoring population behavior changes in relation to reduction in the availability of Ae. aegypti breeding sites. Environmental sanitation policies are also essential to avoid forcing the population to store water under improper conditions and to ensure universal collection and appropriate disposal of household garbage, tires, and other containers.

\section{Final remarks}

The current epidemiological situation with dengue in the Americas and in nearly all countries of the world affected by the disease has posed uncertainties for researchers and health officials concerning the magnitude and severity of future outbreaks of the disease. Dengue cases in travelers have also raised concern among unaffected countries. More than a thousand non-autochthonous cases of dengue have been diagnosed in Europe, a region still free of autochthonous cases. This situation has concerned the European Community, which has warned travelers and developed specific surveillance and diagnostic systems for these individuals. Brazil ranks fifth among the countries that export dengue cases to Europe 64, a highly uncomfortable situation that was aggravated by the recent identification of $A e$. albopictus in Spain 65 , since it poses an additional problem with the international flow of persons from dengue-endemic and epidemic areas.

Even considering the potential protective role of the high proportion of African descendants in the Brazilian population against the emergence of severe forms of the disease, it is still highly probable that new epidemic waves of dengue fever will be accompanied by an increase in the incidence of dengue hemorrhagic fever. To the extent that three of four dengue virus serotypes are circulating (DEN-1, DEN-2, DEN-3) and that there is high probability that DEN-4 will be introduced into the country, the prospects are for new 
and large-scale dengue fever epidemics to occur. In addition, the birth cohorts will constantly replenish the reserves of individuals susceptible to the serotypes currently circulating or that have circulated previously in each city, thereby favoring the occurrence of other epidemics and important changes in the age and severity pattern of these events, as experienced in Rio de Janeiro in 2008, regardless of the introduction of DEN-4.

Twenty-five years since the reemergence of dengue virus infections in Brazil, the disease has contributed significantly to changes in the country's morbidity profile, and if the upward trend in the incidence of dengue hemorrhagic fever that began in 2002 persists, it may also significantly influence the country's mortality profile related to infectious diseases. Although not a consensus 66 , according to some authors, progressive global warming is one of the factors that has favored the reemergence and rapid spread of dengue, by expanding the stretches of territory favorable to infestation by Ae. aegypti 67,68 and other Aedes species that could become competent vectors for the dengue virus. If there are no effective vector control alternatives to overcome the current technical, scientific, and operational difficulties, the future prospects are for the problem to become worse, due to an increase in cases of dengue hemorrhagic fever, especially among children.

International initiatives have been launched to push the development of dengue vaccines, but despite the existence of some candidate vaccines, many difficulties are foreseen in obtaining a safe and effective immunogen within a reasonable time frame. The obstacles include characteristics of dengue itself, which has four serotypes, and the complex host immune response, which after infection by one of the serotypes can increase the risk of developing a severe form of the disease when the individual is infected by another serotype. These specificities require a vaccine that is simultaneously effective against all the serotypes, and that offers lasting immunity to rule out the possibility of infection by any wild virus serotype, due to the risk of occurrence of a severe form in individuals with vaccinal antibodies 69 .

Given the above, the only available alternative for specific prevention to control dengue is still vector control, so that Brazil will need to make efforts to adequately implement the currently available strategies in order to enhance the epidemiological impact of interventions. Investments in research and technological development are indispensable to improve the technologies to reduce or eliminate Ae. aegypti populations on a large scale. However, it is important to recall that dengue has its deepest roots in the explosive expansion of the urban environment, with a major portion of the urban population lacking basic environmental infrastructure. Thus, in order for a dengue control program to be sustainable, it requires urban transformations that reduce the odds of the vector's survival and which consequently decrease the transmission force of the virus. 


\section{Resumo}

Este artigo revisita a epidemiologia da dengue no Brasil após 25 anos da sua reemergência discutindo os principais determinantes e implicações no seu controle. Destacam-se peculiaridades clínicas e epidemiológicas desta virose neste país, que ocupa uma das primeiras posições no que diz respeito tanto ao número de casos notificados como no risco de ocorrência desta doença no mundo. Apresentam-se as mudanças que vêm ocorrendo no padrão epidemiológico da doença nos últimos anos, a exemplo do súbito deslocamento de faixa etária na incidência da febre hemorrágica da dengue, discutindo-se os possiveis fatores envolvidos. Particulariza-se a epidemia do Rio de Janeiro, em 2008, o reflexo deste episódio na comunidade internacional e o temor de disseminação da doença para a Europa. Os autores consideram que esta conjuntura aponta para a necessidade da comunidade científica mundial renovar esforços para gerar conhecimentos que possibilitem o aperfeiçoamento e avanço no desenvolvimento de novas ferramentas e estratégias de prevenção da dengue.

Aedes aegypti; Dengue; Doenças Transmissíveis

\section{References}

1. World Health Organization. Dengue net. http:// www.who.int/globalatlas/DataQuery/default.asp (accessed on 26/Sep/2007).

2. Secretaria de Vigilância em Saúde, Ministério da Saúde. Programa Nacional de Controle de Dengue. http://portal.saude.gov.br/portal/arquivos/pdf/ tabela_dengue2007.pdf (accessed on 14/Jul/2008).

3. Halstead SB. Dengue in the Americas and Southeast Asia: do they differ? Rev Panam Salud Pública 2006; 6:407-15

4. Halstead SB. The pathogenesis of dengue. Molecular epidemiology in infectious disease. Am J Epidemiol 1981; 114:632-48

5. Morens DM, Marchette NJ, Chu MC, Halstead SB. Growth of dengue type 2 virus isolates in human peripheral blood leukocytes correlates with severe and mild dengue disease. Am J Trop Med Hyg 1991; 45:644-51.

6. Siqueira Jr. JB, Martelli CT, Coelho GE, Simplício ACR, Hatch DL. Dengue and dengue hemorrhagic fever, Brazil, 1981-2002. Emerg Infec Dis 2005; 11:48-53.

7. Teixeira MG, Costa MCN, Barreto ML, Mota E. Dengue and dengue hemorrhagic fever epidemics in Brazil: what research is needed based on trends, surveillance, and control experiences? Cad Saúde Pública 2005; 21:1307-15.

\section{Contributors}

M. G. Teixeira contributed to the conceptualization and drafting of the article, data analysis and interpretation, and final approval of the version to be submitted for publication. M. C. N. Costa contributed to the conceptualization and drafting of the article and participated in the data analysis and interpretation, critical review of the article, and final approval of the version to be submitted for publication. F. Barreto contributed to the conceptualization and drafting of the article and participated in the data analysis and interpretation, critical review of the article, and final approval of the version to be submitted for publication. M. L. Barreto contributed to the conceptualization and drafting of the article, data analysis and interpretation, critical review of the article, and final approval of the version to be submitted for publication.
8. Nogueira RM, Araújo JM, Schatzmayr HG. Dengue viruses in Brazil, 1986-2006. Rev Panam Salud Pública 2007; 22:358-63.

9. Secretaria de Estado de Saúde e Defesa Civil. Relatório de casos de dengue-2008, Rio de Janeiro. http:/ / www.saude.rj.gov.br/Acoes/Dengue estado.shtml (accessed on 04/Jun/2008).

10. Dengue fever climbs the social ladder [Editorial]. Nature 2007; 448:734-5.

11. Barreto ML, Teixeira MG. Dengue fever: a call for local, national and international action. Lancet 2008; 372:205.

12. Gubler DJ. Dengue and dengue hemorrhagic fever. Clin Microbiol Rev 1998; 11:480-96.

13. Teixeira MG, Barreto ML, Guerra Z. Epidemiologia e medidas de prevenção do dengue. Inf Epidemiol SUS 1999; 8:5-33.

14. Mondinia A, Chiaravalloti Neto F. Spatial correlation of incidence of dengue with socioeconomic, demographic and environmental variables in a Brazilian city. Sci Total Environ 2008; 393:241-8.

15. Costa MCN, Teixeira MG. A concepção de "espaço" na investigação epidemiológica. Cad Saúde Pública 1999; 15:271-9.

16. Martinez-Torres ME. Dengue hemorrágico em crianças: editorial. Habana: José Marti; 1990. 
17. Kuno G. Review of the factors modulating dengue transmission. Epidemiol Rev 1995; 17:321-35.

18. Donalisio MR C. O enfrentamento de epidemias: as estratégias e perspectivas do controle do dengue [Tese de Doutorado]. Campinas: Universidade Estadual de Campinas; 1995.

19. Barreto FR, Teixeira MG, Costa MCN, Carvalho MS, Barreto ML. Spread pattern of the first dengue epidemic in the city of Salvador, Brazil. BMC Public Health 2008; 8:51.

20. Teixeira MG, Barreto ML, Costa MCN, Ferreira LDA, Vasconcelos PFC, Cairncross S. Dynamics of dengue virus circulation: a silent epidemic in a complex urban area. Trop Med Int Health 2002; 7:757-62.

21. Vasconcelos PFC, Lima JWO, Travassos-da-Rosa PA, Timbó MJ, Travassos-da-Rosa ES, Lima HR, et al. Epidemia de dengue em Fortaleza, Ceará: inquérito soro-epidemiológico aleatório. Rev Saúde Pública 1998; 32:447-54.

22. Vasconcelos PFC, Lima JW, Raposo ML, Rodrigues SG, Travassos-da-Rosa JFS, Amorim SMC, et al. Inquérito soro-epidemiológico na Ilha de São Luís durante epidemia de dengue no Maranhão. Rev Soc Bras Med Trop 1999; 32:171-9.

23. Dias JP. Avaliação da efetividade do Programa de Erradicação do Aedes aegypti. Brasil, 1996-2002 [Tese de Doutorado]. Salvador: Instituto de Saúde Coletiva, Universidade Federal da Bahia; 2006.

24. Montesano-Castellanos R, Ruiz-Matus C. Vigilancia epidemiológica del dengue en Mexico. Salud Pública Méx 1995; 37 Suppl:64-76.

25. Teixeira MG, Barreto ML. Porque devemos, de novo, erradicar o Aedes aegypti. Ciênc Saúde Coletiva 1996; 1:122-35.

26. Cunha MCN. Fatores associados à infecção do dengue em Belo Horizonte: características individuais e diferenças intra-urbanas [Tese de Doutorado]. Belo Horizonte. Universidade Federal de Minas Gerais; 2005.

27. Medronho AR. Geoprocessamento e saúde: uma nova abordagem do espaço no processo saúde doença. Rio de Janeiro: Fundação Oswaldo Cruz; 1995.

28. Amaral R, Tauil PL. Duas ameaças e um mosquito: febre amarela e dengue. Saúde Bras 1983; 4:236-8.

29. Osanai CH, Rosa AP, Tang AT, Amaral RS, Passos AD, Tauil PL. Surto de dengue em Boa Vista, Roraima. Rev Inst Med Trop São Paulo 1983; 25:53-4.

30. Figueiredo LTM, Cavalcante SMB, Simões MC. Encuesta serológica sobre el dengue entre escolares de Rio de Janeiro. Brasil, 1986 y 1987. Bol Oficina Sanit Panam 1991; 111:525-33.

31. Sierra BC, Koury G, Guzmán MG. Race: a risk factor for dengue hemorrhagic fever. Arch Virol 2007; 152:533-42.

32. Blanton RE, Silva LK, Morato VG, Parrado AR, Dias JP, Melo PS, et al. Genetic ancestry and income are associated with dengue hemorrhagic fever in a highly admixed population. Eur J Hum Gen 2008; 16:762-5.

33. Melo PRS, Reis EAG, Ciuffo IA, Góes M, Blanton RE, Reis MG. The dynamics of dengue virus serotype 3 introduction and dispersion in the state of Bahia, Brazil. Mem Inst Oswaldo Cruz 2007; 102:905-12.
34. Cunha RV. Estudo soro-epidemiológico sobre dengue em escolares do Município de Niterói, Rio de Janeiro, 1991 [Dissertação de Mestrado]. Rio de Janeiro: Instituto Oswaldo Cruz, Fundação Oswaldo Cruz; 1993.

35. Siqueira JB, Martelli CM, Maciel IJ, Oliveira RM, Ribeiro MG, Amorim FP, et al. Household survey of dengue infection in central Brazil: spatial point pattern analysis and risk factors assessment. Am J Trop Med Hyg 2004; 71:646-51.

36. Figueiredo LTM, Owa MA, Carlucci RH, Oliveira L. Encuesta serológica sobre el dengue en Ribeirão Preto, São Paulo, Brasil. Bol Oficina Sanit Panam 1995; 118:499-509.

37. Cordeiro MT, Schatzmayr HG, Nogueira RMR, Oliveira VF, Melo WT, Carvalho EF. Dengue and dengue hemorrhagic fever in the State of Pernambuco, 1995-2006. Rev Soc Bras Med Trop 2007; 40:605-11.

38. Ooi EE, Goh KT, Gubler DJ. Dengue prevention and 35 years of vector control in Singapore. Emerg Infect Dis 2006; 12:887-93.

39. Guzman MG, Kourí G. Dengue: an update. Lancet Infect Dis 2002; 2:33-42.

40. Guilarde AO, Turchi MD, Siqueira Jr. JB, Feres VC, Rocha B, Levi JE, et al. Dengue and dengue hemorrhagic fever among adults: clinical outcomes related to viremia, serotypes, and antibody response. J Infect Dis 2008; 197:817-24.

41. Rosen L. The emperor's new clothes revisited, or reflections on the pathogenesis of dengue hemorrhagic fever. Am J Trop Med Hyg 1977; 26:337-43.

42. Silveira AC. Dengue: aspectos epidemiológicos e de controle. Rev Soc Bras Med Trop 1998; 31 Suppl 2:5-14.

43. Nisalak A, Endy TP, Nimmannitya S, Kalayanarooj S, Yakorn UT, Scott RM, et al. Serotype-specific dengue virus circulation and dengue disease in Bangkok, Thailand from 1973 to 1999. Am J Trop Med Hig 2003; 68:191-202.

44. Zagne SMO, Alves VG, Nogueira RM, Miagostovich MP, Lampe E, Tavares W. Dengue haemorrhagic fever in the state of Rio de Janeiro, Brazil: a study of 56 confirmed cases. Trans R Soc Trop Med Hyg 1994; 88:677-9.

45. Souza LJ, Alves JG, Nogueira RM, Gicovate Neto C, Bastos DA, Siqueira EW, et al. Aminotransferase changes and acute hepatitis in patients with Dengue fever: analysis of 1585 cases. Braz J Infect Dis 2004; 8:156-63.

46. Ramos C, Sanchez G, Pando RH, Baquera J, Hernandez D, Mota J, et al. Dengue virus in the brain of a fatal case of hemorrhagic dengue fever. J Neurovirol 1998; 4:465-8.

47. Uehara PM, Cunha RV, Pereira GROL, Oliveira PA. Liver involvement in patients with dengue hemorrhagic fever: a rare phenomenon? Rev Soc Bras Med Trop 2006; 39:544-7.

48. Soares CN, Faria LC, Peralta JM, De Freitas MR, Puccioni-Sohler M. Dengue infection: neurological manifestations and cerebrospinal fluid (CSF) analysis. J Neurol Sci 2006; 249:19-24. 
49. Horta-Veloso H, Ferreira Júnior JA, Braga-de-Paiva JM, Faria-Honório J, Junqueira-Bellei NC, Vicenzo-de-Paola AA. Acute atrial fibrillation during dengue hemorrhagic fever. Braz J Infect Dis 2003; 7:418-22.

50. Torres JR, Liprandi F, Gonçalvez AP. Acute parotitis due to dengue virus. Clin Infect Dis 2000; 31:E28-9.

51. Gulati S, Maheshwari A. Atypical manifestations of dengue. Trop Med Int Health 2007; 12:1087-95.

52. Special Programme for Research \& Training in Tropical Diseases. Report on dengue. http//www. who.int/tdr (accessed on 24/Jan/2008).

53. Ministério da Saúde/Fundação Nacional de Saúde. Programa Nacional de Controle de Dengue. Brasília: Ministério da Saúde/Fundação Nacional de Saúde; 2002

54. Cunha RV, Dias M, Nogueira RMR, Chagas N, Schatzmayr HG. Secondary dengue infection in schoolchildren in a dengue endemic area in the State of Rio de Janeiro, Brazil. Rev Inst Med Trop São Paulo 1995; 37:517-21.

55. Tauil PL. Aspectos críticos do controle do dengue no Brasil. Cad Saúde Pública 2002; 18:867-71.

56. Newton EA, Reiter P. A model of the transmission of dengue fever with an evaluation of the impact of ultra-low volume (ULV) insecticide applications on dengue epidemics. Am J Trop Med Hyg 1992; 47:709-20.

57. Donalísio MR, Alves MJC, Visockas A. Inquérito sobre conhecimentos e atitudes da população sobre a transmissão da dengue - região de Campinas, São Paulo-Brasil, 1998. Rev Soc Bras Med Trop 2001; 34:197-201.

58. Claro LBL, Tomassini HCB, Rosa MLG. Prevenção e controle do dengue: uma revisão de estudos sobre conhecimentos, crenças e práticas da população Cad Saúde Pública 2004; 20:1447-57.

59. Chiaravalloti NF, Baglini V, Cesarino MB, Favaro EA, Mondini A, Ferreira AC, et al. O programa de controle do dengue em São José do Rio Preto, SP: dificuldades para a atuação dos agentes e adesão da população. Cad Saúde Pública 2007; 23:1656-64.
60. Gama RA, Silva ES, Silva IM, Resende MC, Eiras AE. Evaluation of the sticky MosquiTRAP ${ }^{\circledR}$ for detecting Aedes aegypti Linnaeus (Diptera: Culicidae) during the dry season in the district of Itapoã, Belo Horizonte, Minas Gerais, Brazil. Neotrop Entomol 2007; 36:56-64.

61. Bracco JE, Capurro ML, Lourenço-de-Oliveira R Sallum MAM. Genetic variability of Aedes aegypti in the Americas using a mitochondrial gene: evidence of multiple introductions. Mem Inst Oswaldo Cruz 2007; 102:573-80.

62. Speranca MA, Capurro ML. Perspectives in the control of infectious diseases by transgenic mosquitoes in the post-genomic era. Mem Inst Oswaldo Cruz 2007; 102:425-33.

63. Geier M, Rose A, Eiras ÁE. A new lure for host-seeking anthropophilic mosquitoes and a novel type of a simple, non-CO2 mosquito trap. Int J Med Microbiol 2004; 293 Suppl 38:50.

64. Diseases of Environmental and Zoonotic Origin Team European Centre for Disease Prevention and Control. Dengue worldwide: an overview of the current situation and the implications for Europe. Euro Surveill 2007 21; 12(6):E070621.1.

65. Alice M. Mosquitoes! The resident. http:// portugalresident.com/portugalresident/showsto ry.asp?ID=14489 (accessed on 02/Jun/2008).

66. Reiter P. From Shakespeare to Defoe: malaria in England in the Little Ice Age. Emerg Infect Dis 2000; 6:1-11.

67. Hales S, Wet N, Maindonald J, Woodward A. Potential effect of population and climate changes on global distribution of dengue fever: an empirical model. Lancet 2002; 360:830-4.

68. World Health Organization. WHO report on global surveillance of epidemic-prone infectious diseases. Geneva: World Health Organization; 2000.

69. Whitehead SS, Blaney JE, Durbin AP, Murphy BR. Prospects for a dengue virus vaccine. Nature 2007; 5:518-28.

Submitted on 19/Feb/2008

Final version resubmitted on 23/Jun/2008

Approved on 03/Jul/2008 